\title{
Mechanical properties and corrosion resistance of some titanium alloys in marine environment
}

\author{
Jennifer Dupuis ${ }^{1,2}$, M. Chenon ${ }^{2}$, S. Faure ${ }^{3}$, F. Razan ${ }^{3}$ and T. Gloriant ${ }^{1}$ \\ 1 INSA Rennes, UMR CNRS 6226 Sciences Chimique de Rennes/Chimie-métallurgie, 20 avenue des Buttes \\ de Coësmes, 35708 Rennes Cedex 7, France \\ 2 PONTOS, ZI SUD, 7 rue du Mottais, 35400 Saint-Malo, France \\ ${ }^{3}$ ENS CACHAN Antenne de Bretagne, Avenue Robert Schuman, 35170 Bruz, France
}

\begin{abstract}
Titanium alloys are used in several fields such as aerospace industry or biomedical. They are increasingly used in marine applications, a highly corrosive environment. We chose titanium alloys for their good properties such as high mechanical strength, low density and excellent corrosion resistance. This study is focused on titanium alloys potentially interesting to be used in marine transports, and mainly for the boats fittings such as a winch for example.
\end{abstract}

\section{INTRODUCTION}

The marine environment exposes the materials to conditions which can generate their degrading. Several modes of degrading exist such as sea air, seawater, and bacteria. It is necessary to evaluate the materials resistance to corrosion and to determine ways to protect them against degradations created by this environment.

In this study, we chose to study titanium alloys for their good mechanical properties, low density and excellent corrosion resistance. First, metallurgical and mechanical characterizations have been done. Then, corrosion tests have been done with a three-electrodes setting in three different electrolytes. Measurements selected are corrosion potential and current density according to the potential value applied. We are trying to define experimental Tafel parameters.

In order to optimize the mechanicals properties, thermal treatments have been done. On the other hand, surface treatments have been also done to increase the corrosion resistance of the materials in marine environment. Corrosion tests have been done on different titanium alloys with or not surface treatments in three electrolytes ( $3 \mathrm{pH}$ values 1.33_7.68_12.22).

Information in this study is needed to select the alloy which is most resistant to environmental and mechanical stress. The tests allow us to choose the most appropriate material for our marine applications with a specific surface treatment.

\section{EXPERIMENTAL TECHNIQUES AND MATERIALS}

Before characterizing alloys, heat treatments have been done (solution heat treatment followed by quenching, coldrolling process, recrystallization and aging treatment) [1, 2]. Characterizations have been done for the recrystallized and aged materials.

Microstructure observations were carried out by using an optical microscope and a scanning electron microscopy (CMEBA system). Samples were first polished

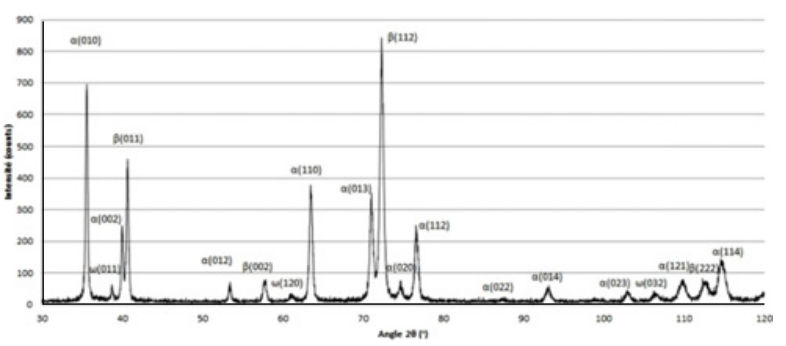

Figure 1. X-ray diffractogram for Ti-6.8 Mo-4.5 Fe-1.5 Al, after aging treatment.

and then etched with a hydrous solution consisting of $2.5 \% \mathrm{HF}, 2.5 \% \mathrm{HNO}_{3}$ and $95 \% \mathrm{H}_{2} \mathrm{O}$. X-ray diffractions were performed with a Philips generator system (copper $\mathrm{K} \alpha_{1}$ radiation). Mechanical characteristics have been determined by tensile tests (INSTRON 3369 with a deformation rate of $10^{-4} \mathrm{~s}^{-1}$ ) and by Vickers microhardness measurements.

The device used for corrosion tests was a threeelectrodes setting (VoltaLab PGZ100) [3-5]. An artificial seawater was used to simulate the marine environment and to compare the results obtained in different electrolytes.

\section{EXPERIMENTAL RESULTS}

The following experimental results are obtained for a metastable $\beta$ titanium alloy, Ti-6.8 Mo-4.5 Fe-1.5 Al.

\section{a) Microstructure}

Figure 1 shows an X-rays diffractogram for Ti-6.8 Mo-4.5 $\mathrm{Fe}-1.5 \mathrm{Al}$.

The peaks observed belong to $\alpha$ and $\beta$ phase of titanium and show that Ti-6.8 Mo-4.5 Fe-1.5 Al is an $\alpha / \beta$ phases mixing. $\beta$ phase is stable at high temperature and $\alpha$ phase is stable at low temperature. The molybdenum and iron alloying elements are classified as $\beta$-stabilizers, they stabilize the $\beta$ phase field to room temperature. Some minority peaks showing the $\omega$ phase presence in the alloy 


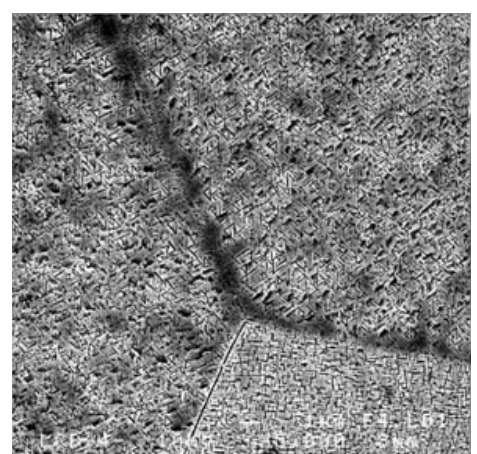

Figure 2. Microstructure of Ti-6.8 Mo-4.5 Fe-1.5 Al observed with a SEM.



Figure 3. Ti-6.8 Mo-4.5 Fe-1.5 Al Tafel curve in $\mathrm{NaCl} 3 \%$ electrolyte.

can be observed. This phase appeared during the slow cooling following the aging.

Lattice parameters obtained for this diffractogram are the following:

$\alpha$ phase (hexagonal close packed): $\mathrm{a}=2.94 \AA$ et $\mathrm{c}=4.68 \AA$

$\beta$ phase (body-centered cubic): $\mathrm{a}=3.2085 \AA$

Microstructure (SEM observations) is shown in Figure 2:

$\beta$ grains triple joint (with $\alpha$ phase fine lamellae) can be observed. b) Mechanicals properties

For Ti-6.8 Mo-4.5 Fe-1.5 Al, following results after heat treatment, are:

$>$ Vickers microhardness: $450 \mathrm{HV}_{0,3}$ (average with 20 measures)

> Tensile strength: $1400 \mathrm{MPa}$.

c) Corrosion tests

Ti-6.8 Mo-4.5 Fe-1.5 Al Tafel curve is shown in figure 3 .

Following parameters are graphically determined:

Corrosion potential: $\mathrm{E}_{\mathrm{corr}}=0 \mathrm{~V}$

Current density: $\mathrm{J}_{0}=1.38 \times 10^{-5}$ A.m $\mathrm{m}^{-2}$

Anodic Tafel parameter: $\beta_{a}=-0.299 \mathrm{~V}$

Cathodic Tafel parameter: $\beta_{c}=0.294 \mathrm{~V}$

\section{CONCLUSION}

Ti-6.8 Mo-4.5 Fe-1.5 Al characterizations give good results. This alloy study will go further with corrosion characterization on surface treated samples. Others titanium alloys will be also studied.

\section{References}

[1] O.M. Ivasishin, P.E. Markovsky, Yu. V. Matviychuk, S. L. Semiatin, C. H. Ward, S. Fox (2008) "A comparative study of the mechanical properties of high-strength $\beta$-titanium alloys", Journal of Alloys and Compounds 457, 296-309.

[2] Frédéric Prima (2000), « Etude métallurgique d'un nouvel alliage de titane $\beta$-métastable », thesis presented by Institut National des Sciences Appliquées de Rennes.

[3] J. Bénard, A. Michel, J. Philibert et J. Talbot, « Métallurgie générale », $2^{\text {ème }}$ édition, collection Masson.

[4] C. Kotz, M. Treichel, Jr. (2003), « Chimie des solutions », collection de boeck.

[5] F. Dabosi, G. Beranger, B. Baroux (1994), « Corrosion localisée $\gg$, collection Les éditions de physique. 